\title{
Ameliyathanede Çalışan Sağlık Profesyonellerinde Tükenmişlik, İş Doyumu ve Depresyon
}

\author{
Burnout, Job Satisfaction, Depression on the Healthcare \\ Professionals Working in the Operation Room
}

\author{
Muhammet Emin Naldan ${ }^{1}$ \\ Ali Karayağmurlu² \\ Murat Yayık \\ Muhammet Ali Arı ${ }^{4}$
}

${ }^{1}$ Erzurum Regional Training and Research Hospital, Department of Anesthesiology and Reanimation, Erzurum, Turkey

${ }^{2}$ Istanbul University, Faculty of Medicine, Department of Child and Adolesan

Psychiatry, Istanbul, Turkey

${ }^{3}$ Erzurum Regional Training and Research Hospital, Department of Anesthesiology and Reanimation, Erzurum, Turkey

${ }^{4}$ Atatürk Üniversity, Department of

Anesthesiology and Reanimation, Erzurum, Turkey

Geliş Tarihi/Received: 7 Temmuz 2018 Kabul Tarihi/Accepted: 12 Aralık 2018

Yazışma Adresi: Muhammet Emin Naldan, Erzurum Regional Training and Research Hospital, Department of Anesthesiology and Reanimation, Erzurum, Turkey

e-mail:muhammetnaldan@gmail.com

\section{ORCID}

Muhammet Emin Naldan

https://orcid.org/0000-0002-7492-1975

\begin{abstract}
Öz
Amaç: Bu çalışmada ameliyathanede çalışan sağlık personellerinin tükenmişlik, mesleki doyum, depresyon belirti düzeylerini ve bunları etkileyen sosyodemografik özellikleri belirlemek amaçlanmıştır Gereçler ve Yöntem: Araştırmanın örneklemini, Erzurum Bölge Eğitim Araştırma Hastanesi ve Atatürk Üniversitesi Tıp Fakültesi Hastanesi ameliyathanesinde çalışan anestezi doktoru, cerrahi hemşire, anestezi teknisyeni olmak üzere toplam 230 kişi oluşturmuştur. Çalışmada, Sosyodemografik Veri Formu, Maslach Tükenmişlik Ölçeği( MTÖ), Minnesota Doyum Ölçeği (MDÖ) ve Beck Depresyon Envanterini (BDE) doldurmaları katılımcılardan istendi.

Bulgular: Haftada 60 saatin üzerinde çalışan ameliyathane personelinde Duygusal Tükenme (DT) Duyarsızlaşma (D) ve Beck Depresyon Envanteri (BDE) puanları anlamlı biçimde daha yüksek, Kişisel Başarı (KB) puanları düşüktü. $(p<0.05)$ Üniversite hastanesinde çalışanların $D T$, BDE ve D puanları arasındaki fark istatistiksel olarak anlamlıdır. $(p<0.05)$ Doktorların DT ve $D$ puanları, yüksek bulundu $(p<0.05)$ Calışanların BDE ile MDÖ ve KB ölçek puanları arasında negatif yönde anlamlı bir ilişkinin olduğu; DT ve D alt boyutlarından aldıkları puan ortalamaları arasında pozitif yönde anlamlı bir ilişki olduğu bulundu. $(p<0.05)$

Sonuç: Hastalara etkili, doğru ve hızlı müdahale gerektiren yoğun iş baskısı altındaki bir birim olan ameliyathane çalışanlarının ruh sağlıklarını ve çalışma koşullarını değerlendirip, çalışanların iş baskıs ve yükünü azaltmak, ruh sağlığını koruyarak işlevselliğini artırarak hizmet kalitesinin artması açısından faydalı olacaktır.
\end{abstract}

Anahtar Kelimeler: Ameliyathane, sağlık çalışanları, tükenmişlik, iş doyumu, depresyon

\section{Abstract}

Aim: In this study, it was aimed to determine burnout, occupational satisfaction, depression symptom levels and sociodemographic characteristics affecting health personnel working in the operating room.

Materials and Methods: The sample of the study consisted of a total of 230 people, including an anesthesiologist, a surgical nurse and an anesthesia technician working in the Erzurum Regional Training and Research Hospital and Atatürk University Medical Faculty Hospital. In the study, the Sociodemographic Data Form, Maslach Burnout Inventory, Minnesota Satisfaction Scale and Beck Depression Inventory were requested from participants

Results: Emotional Exhaustion, Desensitization and Beck Depression Inventory scores were significantly higher and Personal Achievement scores were lower in operating room personnel working more than 60 hours a week $(p<0.05)$. Desensitization scores were found to be significantly higher $(p<0.05)$. Doctors Emotional Exhaustion and Desensitization scores were high $(p<0.05)$. There was a significant negative correlation between the Beck Depression Inventory and the Minnesota Satisfaction Scale and Personal Achievement scale scores of the employees; There was a significant positive correlation between the mean scores of the Emotional Exhaustion and Desensitization subscales $(p<0.05)$

Conclusion: The operating room, which is a unit under intensive work pressure that requires effective, accurate and rapid intervention, will be useful in evaluating the mental health and working conditions of employees, reducing the work pressure and burden of employees and increasing the quality of service by increasing mental health and functioning.

Key words: Operating room, healthcare professionals, burnout, job satisfaction, depression

\section{GíRiş}

Herbert Freudenberger, 1974 yılında Tükenmişlik Sendromu'nu tanımladığından bu yana bu sendrom hakkında binlerce bilimsel makale yayınlanmıştır ve bu eğilim azalır gibi görünmemektedir. Duygusal tükenme, duyarsızlaşma ve meslekte kişisel başarıyı azaltma ile karakterize bir sendrom olarak tanınan yapı, eleştirilmiş, sorgulanmış ve derinlemesine değişikliklere maruz bırakılmıştır $(1,2)$. Jackson ve Maslach 'ın çalışmasında bu sendromda 3 temel yapı görülmektedir: Depersonalizasyon, bireysel beceri ve başarıda düşme, duygusal tükenmişlik. Tükenmişlik sendromunun başlangıcında duygusal tükenme görülmekte ve kişi işinde fazla yorulmaya ve işi için
Atıf Yapmak İçin: Naldan ME, Karayağmurlu A, Yayık M, Arı ME. Ameliyathanede Çalışan Sağlık Profesyonellerinde Tükenmişlik, İş Doyumu ve Depresyon. Selcuk Med J 2019;35(3): 152-158
Açıklama: Yazarların hiçbiri, bu makalede bahsedilen herhangi bir ürün, aygıt veya ilaç ile ilgili maddi çıkar ilişkisine sahip değildir. Araştırma, herhangi bir dıs organizasyon tarafından desteklenmedi. Yazarlar calışanın birincil verilerine tam erişim izni vermek ve derginin talep ettiği takdirde verileri incelemesine izin vermeyi kabul etmektedirler. 
gerekli zihinsel güce ulaşamamaya başlamaktadır. Sonrasında gelişen depersonalizasyon aşamasında çalışanların hizmet verdikleri kişilere birer insan değilde, nesne gibi muamele etme şeklinde ortaya çıkmaktadır. Bu durumun, kişinin duygusal izolasyonu ile stresten uzaklaşmaya çalışması nedeniyle geliştiği düşünülür. Kişi, sıklıkla başarılı olamaz ve tükenmişliğin son evresinde görülen bireysel beceri ve başarıda düşme, işe ve iş icabı rastlanan kişilerle ilişkilere bağlı başarı ve yeterlilik duygularında azalma görülmeye başlar (3).

Yoğun çalışma ve fazla efor gerektiren (zaman, duygusal katıım, empati), az kazanım ve sıkıntılı çalışma koşulları olan mesleklerde tükenmişlik sıklıkla gözlenmektedir (1). Bu meslekler içerisinde en sıkıntılı ve riske maruz kalan gruplardan biri de ameliyathane çalışanlarıdır. Bu konuyla ilgili yapılan bir çalışmada anesteziyologlarda strese neden olan bazı etmenler çalışmalarda görülmüştür. Bunlar yapılan işlemlerin çok kompleks olması, iş yükünün fiziksel ve zihinsel anlamda fazla olması, zamanın kısıtlı olması, işlemlerin kolektif olması, iletişim sıkıntıları, yaşanabilecek etik sıkıntılar ve iş kontrolünde güçlük çekme olarak tesbit edilmiştir (4).

Çalışanlarda iş doyumu azalıp tükenmişlik başladığında psikolojik sıkıntılar da baş göstermeye başlamaktadır. Böyle kişilerde depresyon sıklığında artış gözükmekte, yaptıkları işlerden haz alma hisleri çok azalmaktadır.

Ameliyathane; yoğun bakım ünitesi, preoperatif değerlendirme, akut ve kronik ağrının yönetimi, acil servis alanında çalışmalarla, hastanedeki hastaların \%40-50'sine hizmet vermektedir $(5,6)$. $\mathrm{Bu}$ alanların tümü, güvenlik, bakım ve verim kalitesi konusunda yüksek talepler ortaya koymaktadır. Bu koşullar altında ameliyathane çalışanları çok ciddi bir strese maruz kalmakta, bu nedenle depresif bir durum sergileyebilmekte, uyumsuzluk, başarısızlık, tükenmişlik sendromu gibi hayat kalitelerini ve iş başarılarını etkileyebilecek ciddi sıkıntılara maruz kalabilmektedirler.

Ameliyathane çalışanlarında tüm bu stres faktörlerine ek olarak uzun süreli anestezik ajanlara maruz kalma sonucunda gelişen hastalıklar , sürekli kapalı ortamda çalışmaları, çalıştıkları saatler boyunca dikkatli olma zorunluluğu gibi nedenlerden dolayı alkol ve madde bağımlıı̆̆ı, anksiyete, tükenmişlik, depresyon, intihar girişimi gibi sık yaşanan problemler görülmektedir. Bu nedenlerden dolayı hasta güvenliği konusunda önemi tartışılmaz olan ameliyathane çalışanlarının iş stresi ve tükenmişlik düzeyleri saptanmalı ve eğer ciddi problemler gözlemleniyorsa gerekli önlemler alınmalıdır.Yaptığımız literatür taramasında ameliyathane çalışanları içinde ruh sağlığı ile tükenmişlik arasındaki ilişkiyle ilgili pek çalışma bulunmadığını gözlemledik (7).

Sağlık personellerinde tükenmişlik ile ilgili birçok çalışma bulunmakla birlikte bu alanda çok yoğun, ağır iş yükü ve stresli çalışma şartları altındaki ameliyathane çalışanları ile ilgili çok az sayıda çalışma bulunmaktadır. Bunun yanı sıra bu çalışma grubundaki sağlık personellerinin tükenmişlik, mesleki doyum ve depresyon belirti düzeylerini etkileyen faktörlerle ilgili detaylı çalışmalara intiyaç duyulmaktadır. Bu çalışmanın amacı, yoğun çalışma yükü altındaki ameliyathane personelinin tükenmişlik, mesleki doyum, depresyon belirti düzeylerini belirlemek ve bunu etkileyen faktörleri saptamaktır.

\section{GEREÇLER VE YÖNTEM}

Tanımlayıcı ve ilişki arayıcı tipte olan çalışma Ocak-Mart 2018 tarihleri arasında gerçekleştirildi. Çalışmanın evrenini Doğu Anadolu Bölgesindeki en büyük iki hastane olan Erzurum Bölge Eğitim ve Araştırma Hastanesi ve Atatürk Üniversitesi Tıp Fakültesi Hastanesi bünyesindeki ameliyathanelerde çalışan bütün sağlık profesyonelleri (doktor, hemşire, anestezi teknisyeni) oluşturdu. Çalışmada örneklem seçme yöntemine gidilmedi. Araştırmanın yapıldığı tarihler arasında ameliyathanede çalışan ve çalışmaya katılmayı kabul eden toplam 230 sağlık çalışanına ulaşıldı. Gebelik, doğum izni, hastalık, görevlendirme ve izinli olan sağlık profesyonelleri ile araştırmaya katılmayı kabul etmeyen 60 sağlık profesyoneli çalışma dışı bırakıldı. Çalışmada verileri toplamak için Sosyo Demografik Veri Formu, Beck Depresyon Envanteri, Maslach Tükenmişlik Ölçeği ve Minnesota Doyum Ölçeği uygulandı.

SosyoDemografik VeriFormu'ndasosyodemografik özellikler ve mesleki özellikler ile ilgili toplam 8 soru bulunmaktadır. Bu sorular yaş, cinsiyet, medeni durum, öğrenim durumu, gelir düzeyi, çalışılan kurum, çalışma yılı, haftalık çalışma süresi olmuştur. Beck Depresyon Envanteri 21 sorudan oluşmaktadır.Depresyonda ortaya çıkan belirtileri ölçer. 1961 yılında Beck et al. (8) tarafından oluşturulmuştur. Hisli ise 1988 'de bu envanterin Türkçe formunu oluşturmuştur (9). Değerlendirmede kullanılan parametreler şunlardır; zevk alamama, depresif duygudurum, karamsarlık, uyku bozukluğu,başarısızlık duygusu, beden imajının çarpıtılması, ağlama nöbetleri, suçluluk duyguları, tedirginlik, sosyal çekilme, kararsızlık, çalışma 
inhibisyonu, yorgunluk, kilo kaybı, iştah azalması, libido kaybı ve somatik uğraşlar. Katılımcı her soruda kişinin o andaki psikolojik durumunu tespit etmek için belirlenmiş dört cümleden birini seçer. Her soru sıfır ile üç puan arasında puanlandırılır.Testten alınabilecek en yüksek puan 63 , en düşük puan 0'dır. Test için $\geq$ 17 puan depresyon varlığı olarak kabul edilmiştir.

Maslach Tükenmişlik Ölçeği (MTÖ), Jackson ve Maslach tarafından oluşturulmuştur (10). MTÖ, toplam 22 başlıktan oluşmaktadır. Ölçekte yer alan ifadeler, likert tipi 5 puanlı bir ölçekleme ile derecelerine göre her zaman ise 4 , çoğu zaman ise 3 , bazen ise 2 , çok nadir ise 1 , hiçbir zaman ise 0 olarak işaretlenir. MTÖ üç kısımdan oluşmaktadır bunlar; kişisel başarı, duygusal tükenme ve duyarsızlaşmadır. Duygusal Tükenme (Emotional Exhaustion) hesaplanırken formdaki 1, 2, 3 ,6, 13, 14, 16, 20 nolu maddelerin cevapları olan puanlar toplandı. Bu değerlerin kategorileri belirlenirken 0-16 arası değerler düşük düzey, 17-27 arası değerler orta düzey, 27 ve üzeri yüksek düzey olarak kabul edildi. Duyarsızlaşma (Yabancılaşma, Depersonalisation) skalası için formdaki 5,10,11,15,22 nolu maddelerin cevapları olan puanlar toplandı. Bulunan değer 0-6 arasında düşük düzey, 7-12 arasında ise orta,13 yada üzeri ise yüksek olarak değerlendirildi. Kişisel Başarı (Personal Accomplishment) skalası için formdaki 4,7, $9,12,17,18,19,21$ nolu maddelerin cevapları olan puanlar toplandı. Elde edilen değer 0-31 arası ise yüksek, 32-38 arası ise orta, 39 yada üzeri ise düşük düzey olarak gruplandırıldı.

Sonuçlar tablolarda yüksek, orta ve düşük düzey grupları olarak, skalalara uygun olarak yukarıdaki değer aralıkları içerisinde sınıflandırıldı. Minnesota Doyum Ölçeği (MDÖ), Weiss et al. (11) tarafından geliştirilmiştir ve çeşitli çalışmalarda kullanılan iyi bir iş doyumu ölçütüdür (11) Baycan ise lisansüstü tezinin bir parçası olarak MDÖ 'nin türkçe versiyonunun geçerlilik ve güvenirlik analizini yapmıştır (12). MDÖ 20 parçadan oluşmaktadır; katılımcılar, 1'den (çok memnuniyetsiz) 5'e (çok memnun) kadar değişen, Likert tipi 5 puanlık bir ölçek kullanarak nisbi memnuniyet derecelerini belirtirler. Anket iki kısımdan oluşmaktadır, içsel doyum kısmı; faaliyet, bağımlı, sosyal statü, moral, değişkenlik,güvenlik, sosyal hizmet,yetenek kullanma,yetki, sorumluluk, başarı hissi ve yaratıcılık faktörlerinden oluşmakta, dışsal doyum kısmı ise;yönetici karar verme, kurum politikası, yönetici denetim, terfi,çalışma şartları, ücret politikası ekip uyumu ve onere edilme faktörlerinden oluşmuştur. İçsel doyum 12 parçadan $(1,2$, 3, 4, 7, 8,
$9,10,11,15,16$ ve 20 no'lu ifadeler), dışsal doyum 8 parçadan (5, 6, 12, 13,14, 17, 18 ve 19 no' lu ifadeler) oluşmaktadır.Puanlama 1= Hiç memnun değilim, 2= Memnum değilim, 3= Kararsızım, 4=Memnunum ve $5=$ Çok memnunum şeklinde yapılmaktadır. İçsel, dışsal ve toplam doyum için 1-5 arasında puanlarla puanlandırılmaktadır.

\section{İstatiksel analiz}

Verilerin istatistiksel değerlendirilmesinde SPSS 17 (Statistical Package for Social Sciences) kullanıldı. Nümerik verilerin normal dağılım gösterip göstermediği Kolmogorov Smirnov testi ile değerlendirilmiştir. İki grubun karşılaştırımasında Stutent $t$ test, iki gruptan fazla olanlar için One Way ANOVA kullanıldı. Gruplar arası ilişkinin değerlendirilmesi için Pearson Korelasyon Analizi yapıldı. Tüm testlerde istatistiksel anlamlılık düzeyi olarak $p<0.05$ değeri kabul edildi.

\section{BULGULAR}

Üniversite hastanesinde çalışan sağlık çalışanlarının \%38.5'inin 26-32 yaş arasında, \%59.4'ünün erkek cinsiyetine sahip, yarısının evli, \%35.4'ünün 4000-10.000 TL arası gelirinin olduğu belirlendi. Kamu hastanesinde çalışan sağlık çalışanlarının \%35.8'inin $33-40$ yaş arasında, \%55.2'sinin kadın cinsiyetine sahip, \%67.2'sinin evli, \%64.9'unun 2000-4000 TL arası gelirinin olduğu belirlendi. Çalışanların görev yaptığı hastane ile demografik özellikleri karşılaştırıldığında sahip olunan cinsiyet hariç diğer parametreler açısından gruplar arasındaki farkın istatistiksel olarak anlamlı olduğu belirlendi. Üniversite hastanesinde çalışan sağlık personellerinin \%37.5'inin anestezi teknisyeni olduğu, \%41.7'sinin 1-5 yıldır çalıştığı, \%38.5'inin haftada 45 saatten az çalıştığı saptandı. Kamu hastanesinde çalışan sağlık çalışanlarının \%47'sinin hemşire, \%34.3'ünün 11 yıldan fazla süredir çalıştığı, \%51.5'inin haftada 45 saatten az çalıştığı saptandı. Çalışanların görev yaptığı hastane ile mesleki özellikleri karşılaştırıldığında tüm parametreler açısından gruplar arasındaki farkın istatistiksel olarak anlamlı olduğu belirlendi (Tablo 1).

Sağlık personellerinin çalıştığı hastane ile tükenmişlik ölçeği ve alt boyutları karşılaştırıldığında üniversite hastanesinde çalışanların devlet hastanesinde çalışanlarına göre duygusal tükenme ve duyarsızlaşma alt boyutlarından daha yüksek puan aldıkları ve aralarındaki farkın istatistiksel olarak anlamlı olduğu belirlendi. Ayrıca üniversite hastanesinde çalışan sağlık personellerinin Beck Depresyon Envanterinden ve İş Doyumu Ölçeğinin 
Tabıo 1. Sağlık Çalışanlarının Demografik Özelliklerinin Dağılımı.

\begin{tabular}{|c|c|c|c|c|c|}
\hline & & Çalı & ne & & Test ve p değeri \\
\hline & Ün & site & $\mathrm{Ka}$ & & \\
\hline & $\mathbf{N}$ & $\%$ & $\mathbf{n}$ & $\%$ & \\
\hline Yaş (yıl) & & & & & \\
\hline $18-25$ & 29 & 30.2 & 37 & 27.6 & $x 2=12,147$ \\
\hline $26-32$ & 37 & 38.5 & 31 & 23.1 & $p=0.007$ \\
\hline $33-40$ & 27 & 28.1 & 48 & 35.8 & \\
\hline $41-60$ & 3 & 3.1 & 18 & 13.4 & \\
\hline Cinsiyet & & & & & \\
\hline Kadın & 39 & 40.6 & 74 & 55.2 & $x^{2}=0.393$ \\
\hline Erkek & 57 & 59.4 & 60 & 44.8 & $p=0.531$ \\
\hline Medeni durum & & & & & \\
\hline Evli & 48 & 50.0 & 90 & 67.2 & $x 2=6.866$ \\
\hline Bekar & 48 & 50.0 & 44 & 32.8 & $\hat{p}=0.009$ \\
\hline Gelir düzeyi & & & & & \\
\hline $1000-2000 \mathrm{TL}$ & 24 & 25.0 & - & - & $x 2=47.605$ \\
\hline 2000-4000 TL & 30 & 31.2 & 87 & 64.9 & $p=0.000$ \\
\hline $4000-10.000 \mathrm{TL}$ & 34 & 35.4 & 35 & 26.1 & \\
\hline 10.000 TL ve üzeri & 8 & 8.3 & 12 & 9.0 & \\
\hline Meslek & & & & & \\
\hline Hemşire & 26 & 27.1 & 63 & 47.0 & $x 2=11.484$ \\
\hline Anestezi Teknikeri & 36 & 37.5 & 45 & 33.6 & $p=0.003$ \\
\hline Doktor & 34 & 35.4 & 26 & 19.4 & \\
\hline Çalışma süresi & & & & & \\
\hline 1 yıldan az & 15 & 15.6 & 16 & 11.9 & $x 2=15.647$ \\
\hline $1-5$ yıl & 40 & 41.7 & 27 & 20.1 & $p=0.001$ \\
\hline $5-10 \mathrm{yll}$ & 20 & 20.8 & 45 & 33.6 & \\
\hline 11 yıl ve üzeri & 21 & 21.9 & 46 & 34.3 & \\
\hline Haftalık çalışma sü & & & & & \\
\hline 45 saatten az & 37 & 38.5 & 69 & 51.5 & $x 2=23.919$ \\
\hline $45-60$ saat & 29 & 30.2 & 56 & 41.8 & $p=0.000$ \\
\hline 60 saatten fazla & 30 & 31.2 & 9 & 6.7 & \\
\hline
\end{tabular}

* Sütun yüzdesi alınmıştır.

içsel doyum ölçeğinden daha yüksek puan aldıkları ve aralarındaki farkın istatistiksel olarak anlamlı olduğu saptandı ( $p<0.05$; Tablo 2).

Sağlık çalışanlarının meslekleri ile tükenmişlik ölçeği alt boyutlarının karşılaştırılmasında; doktorların diğer sağlık çalışanlarına kıyasla duygusal tükenme ve duyarsızlaşma alt boyutlarından, anestezi teknisyenlerinin kişisel başarı alt boyutundan daha yüksek puan aldıkları ve aralarındaki farkın istatistiksel olarak önemli olduğu belirlendi. Sağlık çalışanlarının meslek/görevleri ile depresyon ve iş doyumu ölçeği ve alt boyutlarından aldıkları puan açısından aralarındaki farkın istatistiksel olarak anlamlı olmadığı saptandı ( $p>0.05$; Tablo 3).

Sağlık çalışanlarının haftalık çalışma saatleri ile tükenmişlik ölçeği alt boyutlarının karşılaştırılmasında; haftada 60 saat ve üzeri çalışan sağlık çalışanlarının duygusal tükenme ve duyarsızlaşma alt boyutlarından daha yüksek puan aldıkları ve kişisel başarı alt boyutundan daha düşük puan aldıkları, aralarındaki farkın istatistiksel olarak anlamlı olduğu belirlendi. Sağlık çalışanlarının haftalık çalışma saatleri ile depresyon ve iş doyumu ölçeği alt boyutlarından aldıkları puan açısından aralarındaki farkın istatistiksel olarak anlamlı olmadığı saptandı $(p<0.05$; Tablo 2$)$.

Sağlık çalışanlarının meslekteki çalışma süreleri ile tükenmişlik ölçeği alt boyutlarının karşılaştırılmasında; meslekte 1-5 yıldır çalışan personellerin duygusal tükenme ve duyarsızlaşma alt boyutlarından, 1 yıldan az süredir çalışan sağlık personellerinin kişisel başarı alt boyutundan daha yüksek puan aldıkları ve aralarındaki farkın istatistiksel olarak anlamlı olduğu saptandı ( $p<0.05$; Tablo 2). Sağlık çalışanlarının meslekte çalışma süreleri ile depresyon ve iş doyumu ölçeği ve alt boyutlarından aldıkları puan açısından aralarındaki farkın istatistiksel olarak anlamlı olmadığı saptandı ( $p>0.05$; Tablo 2). Sağlık çalışanlarının Beck Depresyon Envanteri ile içsel doyum, dışsal doyum ve genel doyum ölçeklerinden aldıkları puan ortalamaları arasında negatif yönde anlamlı bir 
Tablo 2. Sağlık Çalışanlarının Mesleki Özellikleri ile BDE, DT, D, KB ve Doyum Ölçeğinden Aldıkları Puan Ortalamalarının Karşılaştırılması.

\begin{tabular}{|c|c|c|c|c|c|c|c|}
\hline & $\begin{array}{c}\text { DT } \\
\text { ortalama } \pm S S\end{array}$ & $\begin{array}{c}\text { KB } \\
\text { ortalama } \pm S S\end{array}$ & $\begin{array}{c}\text { D } \\
\text { ortalama } \pm S S\end{array}$ & $\begin{array}{c}\text { BDE } \\
\text { ortalama } \pm S S\end{array}$ & $\begin{array}{l}\text { Genel doyum } \\
\text { ortalama } \pm S S\end{array}$ & $\begin{array}{l}\text { İçsel doyum } \\
\text { ortalama } \pm S S\end{array}$ & $\begin{array}{l}\text { Dişsal doyum } \\
\text { ortalama } \pm S S\end{array}$ \\
\hline \multicolumn{8}{|l|}{ Çalıştığı Hastane } \\
\hline Devlet Hastanesi & $26.22 \pm 7.88$ & $30.10 \pm 5.75$ & $9.58 \pm 4.13$ & $12.62 \pm 8.30$ & $58.37 \pm 14.97$ & $37.02 \pm 9.87$ & $21.24 \pm 7.14$ \\
\hline Üniversite Hast. & $28.94 \pm 6.77$ & $28.75 \pm 5.90$ & $11.67 \pm 4.87$ & $16.11 \pm 9.08$ & $60.36 \pm 12.63$ & $39.79 \pm 8.67$ & $20.71 \pm 5.72$ \\
\hline \multirow[t]{2}{*}{ Test ve $p$ değeri } & $t=-2.737$ & $t=1.741$ & $t=-3.504$ & $t=-3.019$ & $t=-1.060$ & $t=-2.199$ & $t=0.621$ \\
\hline & $p=0.007$ & $p=0.083$ & $p=0.001$ & $p=0.003$ & $p=0.290$ & $p=0.029$ & $p=0.535$ \\
\hline \multicolumn{8}{|l|}{ Meslek } \\
\hline Hemsire & $26.44 \pm 6.63$ & $29.93 \pm 5.73$ & $9.71 \pm 3.34$ & $14.76 \pm 9.56$ & $59.85 \pm 14.19$ & $37.95 \pm 9.95$ & $21.40 \pm 6.55$ \\
\hline Anest.teknisyen & $26.30 \pm 9.08$ & $31.53 \pm 5.90$ & $9.79 \pm 4.84$ & $12.23 \pm 7.67$ & $57.92 \pm 15.30$ & $37.82 \pm 10.12$ & $20.55 \pm 7.16$ \\
\hline Doktor & $30.13 \pm 5.74$ & $26.26 \pm 4.42$ & $12.46 \pm 5.16$ & $15.56 \pm 8.72$ & $59.96 \pm 12.02$ & $39.00 \pm 7.79$ & $21.10 \pm 5.81$ \\
\hline \multirow[t]{2}{*}{ Test ve $p$ değeri } & $F=5.707$ & $F=16.219$ & $F=8.350$ & $F=2.962$ & $F=0.516$ & $F=0.304$ & $F=0.356$ \\
\hline & $p=0.004$ & $p=0.000$ & $p=0.000$ & $p=0.054$ & $p=0.597$ & $p=0.738$ & $p=0.701$ \\
\hline \multicolumn{8}{|c|}{ Haftalık çalıştığı saat } \\
\hline 45 saate kadar & $26.24 \pm 8.37$ & $30.32 \pm 5.89$ & $9.57 \pm 4.03$ & $13.22 \pm 8.80$ & $58.74 \pm 16.07$ & $37.42 \pm 10.49$ & $21.35 \pm 7.38$ \\
\hline $45-60$ saat & $27.21 \pm 6.81$ & $30.00 \pm 5.73$ & $10.42 \pm 4.47$ & $14.94 \pm 8.21$ & $58.04 \pm 12.73$ & $37.84 \pm 9.10$ & $20.07 \pm 6.02$ \\
\hline 60 saat üstü & $30.71 \pm 5.67$ & $26.41 \pm 4.99$ & $12.94 \pm 5.25$ & $14.53 \pm 9.90$ & $62.97 \pm 9.98$ & $40.97 \pm 6.56$ & $22.20 \pm 5.13$ \\
\hline \multirow[t]{2}{*}{ Test ve $p$ değeri } & $F=5.215$ & $F=7.170$ & $\mathrm{~F}=8.289$ & $F=0.960$ & $F=1.760$ & $F=2.106$ & $F=1.667$ \\
\hline & $p=0.006$ & $p=0.001$ & $p=0.000$ & $p=0.384$ & $p=0.174$ & $p=0.124$ & $p=0.191$ \\
\hline \multicolumn{8}{|c|}{ Meslekte çalışma süresi } \\
\hline 1 yıldan az & $23.51 \pm 10.11$ & $30.06 \pm 7.23$ & $9.35 \pm 4.81$ & $11.87 \pm 8.93$ & $64.29 \pm 16.45$ & $41.41 \pm 8.77$ & $23.96 \pm 8.06$ \\
\hline 1-5 yıl & $29.79 \pm 6.65$ & $29.05 \pm 5.36$ & $11.79 \pm 4.49$ & $15.91 \pm 9.01$ & $60.01 \pm 13.52$ & $38.56 \pm 9.64$ & $20.80 \pm 5.91$ \\
\hline $5-10$ yıl & $26.46 \pm 7.45$ & $29.47 \pm 5.77$ & $10.23 \pm 5.15$ & $14.53 \pm 10.00$ & $58.36 \pm 13.64$ & $37.56 \pm 9.80$ & $20.66 \pm 6.50$ \\
\hline 11 yıl üstü & $27.58 \pm 6.26$ & $29.83 \pm 5.75$ & $9.86 \pm 3.59$ & $12.83 \pm 6.78$ & $56.85 \pm 13.40$ & $36.89 \pm 9.10$ & $20.23 \pm 6.31$ \\
\hline \multirow[t]{2}{*}{ Test ve $p$ değeri } & $F=5.645$ & $F=0.291$ & $F=3.017$ & $F=2.159$ & $F=2.163$ & $F=1.764$ & $F=2.525$ \\
\hline & $p=0.001$ & $p=0.832$ & $p=0.031$ & $p=0.094$ & $p=0.093$ & $p=0.155$ & $p=0.058$ \\
\hline
\end{tabular}

Kısaltmalar: BDE: Beck Depresyon Envanteri, D:Duyarsızlaşma, DT:Duygusal Tükenmişlik, KB:Kişisel Başarı

ilişkinin olduğu; duygusal tükenme, duyarsızlaşma alt boyutlarından aldıkları puan ortalamaları arasında pozitif yönde anlamlı bir ilişkinin olduğu ve kişisel başarı alt boyutundan aldıkları puan ortalamaları arasında negatif yönde anlamlı bir ilişkinin olduğu belirlendi (Tablo 3).

\section{TARTIŞMA}

$\mathrm{Bu}$ çalışmada ameliyathanede çalışan sağlık personellerinin tükenmişlik, mesleki doyum, depresyon belirtileri ve bunları etkileyen demografik veriler incelenmiştir. Çalışmamızda bazı önemli sonuçlar elde edilmiştir. Meslekte çalışılan yıl arttıkça duygusal tükenme ve duyarsızlaşmanın arttığı tesbit edilmiştir. Gökçen et al. (13) da yaptıkları çalışmada duygusal tükenmişliğin çalışılan ilk yıllarda düşük olduğunu sonraki yıllarda arttığı sonucuna varmıştır. Fakat Erol et al. (14) yaptıkları çalışmada yaş ve meslekte çalışılan süre ile tükenmişliğin azaldığını tesbit etmiştir. Mesleğe ilk girme heyecanı ile duygusal tükenme ve duyarsızlaşmanın düşük olduğunu, fakat yıl arttıkça yaşanan sıkıntı ve strese bağlı artı̆̆ını düşünmekteyiz. Taycan et al. (15) çalışmasında meslekte çalışılan süre artışı ile kişisel başarı da artmıştır. Fakat bizim çalışmamızda anlamlı bir farklılık gözlemlemedik.

Çalışmamızda elde ettiğimiz önemli bir sonuç sağlık çalışanlarının içerisinde doktor meslek grubunda

Tablo 3. Sağlık Çalışanlarının BDE, DT, D, KB ve Doyum Ölçeğinden Aldıkları Puan Ortalamaları Arasındaki İlişki

\begin{tabular}{lllll}
\hline & & İcsel doyum & Dişsal doyum & Genel doyum \\
\hline BDE & $r$ & -0.261 & -0.334 & -0.313 \\
& $p$ & 0.000 & 0.000 & 0.000 \\
DT & $r$ & -0.348 & -0.426 & -0.449 \\
& $p$ & 0.000 & 0.000 & 0.000 \\
D & $r$ & -0.139 & -0.341 & -0.274 \\
& p & 0.035 & 0.000 & 0.000 \\
KB & r & 0.253 & 0.296 & 0.292 \\
& p & 0.000 & 0.000 & 0.000 \\
\hline
\end{tabular}

BDE: Beck Depresyon Envanteri, D:DuyarsızlaşmaDT: Duygusal Tükenmişlik, KB: Kişisel Başarı 
tükenmişlik ve depresyon belirtilerin anlamlı derecede fazla görülmesiydi. Bu sonuç literatürdeki diğer çalışmaların sonuçları ile tutarlıydı. Erol et al. (14) asistan hekimlerle yaptıkları çalışmada hekimlerin duygusal tükenmişlik ve duyarsızlaşma düzeylerinin yüksek olduğu görülmüştür. Karlıdağ et al. (16) da hekimler üzerinde yaptığı bir çalışmasında duygusal tükenme ve duyarsızlaşma düzeylerini daha yüksek, kişisel başarı düzeylerini daha düşük olduğunu tesbit etmiştir. Çalışmamızdan elde ettiğimiz bir diğer önemli sonuç çalışma saatlerinin artmasıyla ameliyathanede çalışan sağlık çalışanlarının tükenmişlik belirtilerinin artmasıydı. Özellikle haftada 60 saat ve üzeri çalışan ameliyathane çalışanlarında kişisel başarı düşmüş, duyarsızlaşma ve duygusal tükenme anlamlı bir biçimde artmıştır. Çalışmamız diğer çalışmaların sonuçlarıyla paralellik göstermekteydi. Taycan et al. (15) üniversite hastanesinde çalışan hemşirelerle yaptıkları çalışmalarında çalışma saatleri fazla olan hemşirelerin duygusal tükenmişliklerinin diğerlerine göre belirgin bir şekilde yüksek olduğunu tesbit etmiştir. Ayrıca Erol et al. (14) çalışmasında günde 8 saat üzeri çalışanlarda depersonalizasyon, duygusal tükenmişlik ve depresyon düzeylerinin anlamlı yüksek olduğunu belirlemiştir. Uzun çalışma saatlerinin tükenmişlik için risk olduğu birçok çalışmada vurgulanmıştır $(17,18)$.

Çalışmamızda tükenmişlik ve depresyon puanları ile mesleki doyum arasında negatif anlamlı korelasyon saptanmıştır. Gökçen et al. (13) acil çalışanları ile yaptıkları bir çalışmada tükenmişlik düzeyleri ve depresyon puanları yüksek olan çalışanların iş doyumlarının düşük olduğunu gözlemlemişlerdir. Kavlu et al. (19) da benzer bir çalışmayı acil hemşirelerinde yapmış tükenmişlik düzeyleri fazla olan hemşirelerde mesleki doyumun da düşük olduğunu tesbit etmişlerdir. Literatürdeki diğer çalışmalar da bu bulgumuzu desteklemektedir $(20,21)$.

Bu çalışma ameliyathane personelinde tükenmişlik ile ilgili çok önemli bilgiler vermekle beraber içerisinde bazı kısıtılıklar barındırmaktadır. Birincisi örneklem sayısının nisbeten az olmasıdır.Ikincisi depresyon belirtilerinin Beck Depresyon Ölçeği ile değerlendirilmesi ve bir psikiyatrik değerlendirmenin olmaması çalışmanın diğer kısıtlılığıdır. Üçüncüsü, tükenmişlik durumları bağımsız etkileyici faktörler tarafından istatistiksel olarak incelenmemiştir.

Sonuç olarak ameliyathane çalışanlarında tükenmişlik ve depresyon düzeylerinde artış; iş doyumunda ise düşüş saptandı. Tükenmişlik ve depresyon özellikle stresli ortamlarda çalışanlarda sık görülen ve kişilerin hata yapmasına sebep olan bir durumdur. Bunun ameliyathane çalışanlarında fazla olması hem çalışanlar hem de hizmet verilen hastalar açısından olumsuz sonuçlara yol açmaktadır. Tükenmişliğin ve depresyon düzeylerinin düşürülmesi, iş doyumunun artırılması için iş yerinde çalışma saatlerinin, nöbetlerin daha uygun veya makul süreye getirilmesi ve çalışanların motivasyonlarının artırılması için farklı yöntemler geliştirilmesi faydalı olacaktır.

Çıkar Çatışması: Çalışmada herhangi bir çıkar çatışması yoktur.

Finansal Çıkar Çatışması: Çalışmada herhangi bir finansal çıkar çatışması yoktur.

Yazışma Adresi: Muhammet Emin Naldan, Erzurum Regional Training and Research Hospital, Department of Anesthesiology and Reanimation

Address: Regional Training and Research Hospital,Department of Anesthesiology and Reanimation 2500, Yakutiye, Erzurum/ TURKEY

Phone: + 905063803300 Fax:+90 4422325025

e-mail: muhammetnaldan@gmail.com

\section{KAYNAKLAR}

1. Freudenberger HJ. Staff burn-out. J Soc Iss 1974;30.1:15965.

2. Chirico, F. Is burnout a syndrome or an occupational disease? Instructions for occupational physicians. Epidemiol Prev 2017;41(5-6):294-8.

3. Maslach $\mathrm{C}$, Jackson SE, Leiter M et al. Maslach burnout inventory. Palo Alto, CA: Consulting psychologists press, 1986:3463-4.

4. De Robertis E, Tomins P, Knape P. Anaesthesiologists in emergency medicine: The desirable manpower. Eur $\mathrm{J}$ Anaesthesiol 2010;27(3):223-5.

5. Clergue F. Time to considern on physician anaesthesia providers in Europe? Eur J Anaesthesiol 2010;27:761-62.

6. Nyssen AS, Hansez I. Stres and burnout anesthesia. Current opinion in Anaesthesiology 2008; 21:406-11.

7. Kıtaoka K, Masuda S. Academic report on burnout among japanese nurses. Japan J Nursing Sci 2013;10.2:273-9.

8. Beck AT, Ward $\mathrm{CH}$, Mendelson $\mathrm{M}$ et al. An inventory for measuring depression. Arch Gen Psychiatry. 1961;4:561-71.

9. Hisli N. A study of validity of beck depression inventory. Psikoloji Derg 1988;6:118-26.

10. Maslach C, Jackson SE. The measurement of experienced burnout. J Occup Behav 1981;2:99-113.

11. Weiss DJ, Dawis RV, England GW et al. Minnesota studies in vocational rehabilitation. Manual for the minnesota satisfaction questionnaire. Industrial Relations Center, Minneapolis, University of Minnesota, 1967.

12. Baycan AF. Analysis of the several aspects of job satisfaction between different occupational groups. Masters thesis (unpublished), Istanbul, Bogazici University, Institute of Social Sciences, 1985.

13. Gökçen C, Zengin S, Oktay M et al. Burn out job satisfaction and depression in the healthcare personnel who work in the 
emergency department. Anatolian Journal of Psychiatry/ Anadolu Psikiyatri Dergisi 2013;14.2:122-8.

14. Erol A, Saricicek A, Gülseren S. Asistan hekimlerde tükenmislik: Is doyumu ve depresyonla iliskisi/Burnout in residents: Association with job satisfaction and depression. Anadolu Psikiyatri Dergisi 2007;8.4:241.

15. Taycan $O$, Kutlu L, Çimen $S$ et al. Bir üniversite hastanesinde çalışan hemşirelerde depresyon ve tükenmişlik düzeyinin sosyodemografik özelliklerle ilişkisi. Anadolu Psikiyatri Dergisi 2006;7.2:100-8.

16. Karledag R, Suheyla U, Yologlu S. Hekimlerde tükenmişlik düzeylerinin aleksitimi düzeyleriyle ilişkisi. Psikiyatri Dergisi 2001;2.3:153-60.

17. Özyurt A, Hayran $\mathrm{O}$, Sur $\mathrm{H}$. Predictors of burnout and job satisfaction among Turkish physicians. QJM 2006;99:161-9.
18. Rosenberg T, Pace M. Burnout among mental health professionals: Special considerations for the marriage and family therapist. J Marital Fam Ther 2006;32:87-99.

19. Kavlu I, Pınar R. Acil servislerde çalışan hemşirelerin tükenmişlik ve iş doyumlarının yaşam kalitesine etkisi. Turkiye Klinikleri J Med Sci 2009;29.6:1543-55.

20. Faragher EB, Cass M, Cooper CL. The relationship between job satisfaction and health: A metaanalysis. Occup Environ Med 2005;62:105-12.

21. Becker JL, Milad MP, Klock SC. Burnout, depresssion and career satisfaction: Cross-sectional study of obstetrics and gynecology residents. Am J Obstet Gynecol 2006;195:14449. 